Сибирские исторические исследования. 2015. № 3

УДК 346.167;94(4)

DOI: $10.17223 / 2312461 \mathrm{X} / 9 / 8$

Coogan, Tim Pat. The Famine plot:

England's role in Ireland's greatest tragedy. New York, Palgrave Macmillan, 2012. 271 p. ISBN 978-0-230-10952-0

\title{
(Е.П. Власова)
}

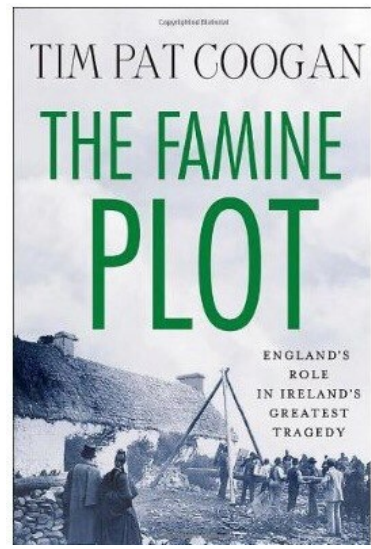

Тим Пэт Куган не нуждается в представлении для всех, кто интересуется историей Ирландии. В настоящее время его называют одним из главных историков этой страны, который посвятил свои труды таким проблемным темам, как Великий голод, эмиграция, конфликт в Северной Ирландии.

В название своей новой работы, вышедшей в 2012 г., Куган выносит основную проблематику исследования - роль англичан в величайшей трагедии Ирландии. Следует отметить, что тема Великого голода, одна из самых изучаемых в ирландской истории, подобно любой другой популярной теме, обросла клише, перевиранием фактов на ранней истории изучения и односторонностью в рассмотрении целого ряда проблем. Тим Пэт Куган выбрал самую деликатную сторону в истории Великого голода - степень вины англичан в ирландской катастрофе. Как уже было сказано выше, изучение данной темы было подвержено ряду историографических проблем. Долгое время причастность англичан к этим событиям замалчивалась в историографии, и акцент делался только на распространении самого грибка-фитофторы, поразившего картофель в Ирландии и по всей Европе в середине XIX в. Тема вины англичан, в том числе и неудачные политические шаги правительства, такие как ввоз индийского зерна, создание работных домов, поощрение продажи земельных участков и стимулирование эмиграции, все чаще стали появляться на страницах исследований, постепенно приближаясь к главному вопросу - была ли эта трагедия, обескровившая Ирландию в два раза, случайной или же спланированной. Монография Кугана принадлежит к новаторским работам по изучению как Великого голода, так и самой истории англо-ирландских отношений, в первую очередь, благодаря широкому фактическому материалу и привлечению большого числа различных источников. 
Исследуя данную тему, Куган касается всех ее аспектов. Он кратко пишет о том, как складывались англо-ирландские отношения в политическом плане и в сфере религии. Далее он весьма красочно описывает условия жизни ирландцев в деревне XIX в.: «Основой их жилища были грязные хижины, покрытые соломой... Любое улучшение дома привело бы к тому, что хозяева подняли бы цену за аренду» (р. 20). Условия жизни были тяжелыми физически и психологически. Крестьяне жили в плохо проветриваемых домах, в единственной комнате, где вынуждены были спать несколько поколений одной семьи. Тяжелые условия жизни наталкивали ирландцев на мысль о том, что женатыми жить проще, чем неженатыми, так как гораздо легче было вести хозяйство. Это привело к тому, что за период с 1741 по 1845 г. население Ирландии возросло в три раза (p. 20-21). К середине XIX в. это была самая густонаселенная страна Европы (История Ирландии 1980: 186). В самый обычный год были «голодные месяцы», продолжавшиеся с марта по июль - с момента посадки картофеля до первого сбора урожая. Как говорят в народе, картофель в Ирландии растет от «Падди до Билли» - со Дня Святого Патрика, который празднуют 17 марта, до Дня Вильгельма Оранского, отмечаемого 12 июля (р. 21). Ирландия XIX в. нуждалась в реформировании земельной системы, развитии инфраструктуры, строительстве портов и мостов (p. 31). Тем не менее автор не останавливается на описании жизни в Ирландии, освещая подробно лишь роль «Закона о бедных» 1834 г., по которому предусматривалось создание работных домов и ни один работоспособный человек не имел права получать никакую помощь от местной администрации, кроме как в подобных домах. Условия труда и жизни в работных домах были просто нечеловеческими.

Рассказывая о политике англичан в Ирландии, Куган персонализирует ее, подробно останавливаясь на личностях ответственных и за «Закон о бедных», и за политику во время Великого голода. Если раньше все это описывалось совокупной политикой партии вигов, то в данной книге подробно освещаются слова и действия английских политиков в Ирландии. Куган называет их «пятью актерами» (р. 43). Это были два премьер-министра Великобритании - консерватор сэр Роберт Пил (1842-1846) и следующий за ним лорд Джон Рассел (1846-1852). Другими двумя игроками были министр финансов Сэр Чарльз Вуд и министр внутренних дел Сэр Джордж Грей. Но главную роль автор отводит заместителю министра финансов - Сэру Чарльзу Тревеляну, который, по его мнению, был основной фигурой в истории ирландского голода. «Даже если Тревелян был гражданским служащим, пусть и возвеличенным, в то время как ирландский голод чеканился в наковальне политики вигов, именно Тревелян наносил удары молотом» (р. 101). Среди важных политических фигур того времени со стороны ирландцев была лишь тающая во времени личность Дэниела О'Коннелла, который 
тяжело перенес тюремное заключение и умер в 1847 г. (р. 43-44). Важную роль Куган отводит не только действиям своих героев, но и их словам. Он подробно останавливается на речи Тревеляна, в которой тот весьма уничижительно отзывается об ирландцах, и даже приводит полный ее текст в приложении. Повествование о политических шагах Тревеляна подкрепляется его многочисленными высказываниями о своей работе и подвластном ему народу, вроде «ирландское имущество должно быть оплачено ирландской бедностью» (р. 163).

Также Куган анализирует действия протестантской церкви во время Голода. Когда создание «суповых кухонь» сопровождалось не только антисанитарией и плохим рецептом этого самого «супа», представлявшего из себя часто лишь муку с водой, но и таким обязательным условием его получения, как переход в протестантскую религию. «Голодающие католики нуждаются не в еде, а в Библии» - так говорили английские священники в то время (р. 147).

Таким образом, в 13 главах своей книги автор останавливается на каждом моменте, связанном с Великим голодом - от описания обстоятельств, при которых начался голод, до эмиграции в Америку и основных последствий голода для Ирландии. Среди наиболее интересных и новаторских сюжетов книги стоит также отметить главу о жизни ирландских лордов во время печальных событий (р. 179-188).

Куган наполняет монографию многочисленными историями из жизни простых ирландцев, широко привлекая для этой цели архивные и литературные материалы - письма, газетные статьи, дневники, поэзию.

С антропологической точки зрения эта работа весьма интересна благодаря подробнейшим сведениям о жизни ирландцев XIX в., богатому эпистолярному материалу и тому, что, как уже говорилось выше, это монография об англо-ирландских отношениях. Описывая антагонизм двух народов, приводя цитаты английских политических и религиозных лидеров, рассказывая о той пропаганде, которую вели англичане во время Голода, и той дискриминации, которой они подвергали ирландцев в печати, Куган, тем не менее, не говорит о самом главном. Каждая глава говорит читателям о той роли, какую англичане сыграли в трагедии Великого голода в Ирландии, но главные слова автор так и не произносит. Эти слова расизм и геноцид. Избегая неловкости в обвинении англичан в геноциде, автор приводит в приложении цитаты из Конвенции ООН касательно геноцида. Он как бы подводит своих читателей к этой мысли, но сам весьма деликатен с выводами. На протяжении всей книги он ни разу не пишет напрямую о том, что это был именно геноцид. Такая же ситуация и с расизмом. Говоря об англо-ирландских отношениях, автор приводит все доводы к тому, что это было не просто религиозное и политическое противостояние, это именно ненависть англосаксов к кельтам, к народу, который они считали ниже по статусу. И монография, которая касается наиболее 
острого вопроса ирландской истории, которая предельно качественно и добросовестно подобрала аргументацию, утонула в главном историографическом клише последних лет. Дело в том, что работа Кугана подхвачена темой «эмиграции национализма», основной линии изучения эмиграции из Ирландии и самого Великого голода. Великий голод спровоцировал эмиграцию, эмиграция подарила ирландскую независимость. Ведь именно в США появились первые филокельтские движения, группировки, которые помогали своим соотечественникам, оставшимся дома.

В результате исследования Куган приходит к тому выводу, к той самой цепочке - Великий голод - эмиграция - независимость Ирландии, к которой уже пришли до него (например, Scally 1995), просто наполнив ее новыми фактами и остротой противостояния с англичанами. Но саму природу этого противостояния, этой ненависти друг к другу он не указал. Вопросы о степени вины и причастности англичан к Великому голоду поднимаются на занятиях в высших учебных заведениях Ирландии, обсуждаются на конференциях, но так и не появляются в печатных изданиях. Сами ирландцы говорят, что вместо «геноцид ирландского народа» они произносят «Великий голод». Монографию Тима Пэт Кугана можно рассматривать в качестве примера того, как наиболее важные темы в истории изучаются с осторожностью и политической деликатностью. Тема англоирландских отношений все еще сложна для изучения и свидетельствует о том, что последствия Кризиса в Северной Ирландии не решены до конца. Исследования по истории Ирландии обычно заканчиваются либо словами о Соглашении Страстной Пятницы, либо о том, что в Белфасте все еще стоит стена, разделяющая район города на католическую и протестантскую стороны. Тим Пэт Куган заканчивает свою книгу словами о Соглашении Страстной Пятницы, но ведь стена в Белфасте все еще стоит.

Е.П. Власова

Московский государственный университет

\section{Лuтература}

История Ирландии / Под ред. Л.И. Гольмана. М.: Мысль, 1980. 394 с.

Scally R.J. The End of the Hidden Ireland. Rebellion, Famine, and Emigration. Oxford: Oxford University Press, 1995. $261 \mathrm{p}$.

Рецензия поступила в редакцию 1 августа 2015 г.

Vlasova Elena P., Moscow State University (Moscow, Russian Federation).

Coogan, Tim Pat. The Famine plot: England's role in Ireland's greatest tragedy. New York, Palgrave Macmillan, 2012. 271 p. ISBN 978-0-230-10952-0

DOI: $10.17223 / 2312461 \mathrm{X} / 9 / 8$

\section{References}

Istoriia Irlandii [The History of Ireland], Ed. by L.I. Gol'man. Moscow: Mysl', 1980. 394 p. Scally R.J. The End of the Hidden Ireland. Rebellion, Famine, and Emigration. Oxford: Oxford University Press, 1995. 261 p. 